\title{
PRESENCE OF GLYPHOSATE CAN HARM THE GERMINATION OF BEAN SEEDS TREATED WITH BIOSTIMULANT
}

\author{
PRESENÇA DE GLIFOSATO PODE PREJUDICAR A GERMINAÇÃO DE \\ SEMENTES DE FEIJOEIRO TRATADAS COM BIOESTIMULANTE
}

\author{
Jorgiani de ÁVILA ${ }^{1}$; Fernanda Brito CARDOSO ${ }^{2}$; Sebastião Ferreira de LIMA ${ }^{2}$; \\ Gustavo Ribeiro BARZOTTO ${ }^{1}$; Mayara Santana ZANELLA ${ }^{3}$ \\ 1. Universidade Estadual Paulista - UNESP/FCA, Departamento de Horticultura, Botucatu, SP, Brasil; 2. Universidade Federal de \\ Mato Grosso do Sul, Chapadão do Sul, MS, Brasil. sebastiao.lima@ufms.br; 3. Universidade Federal de Mato Grosso do Sul, Instituto \\ de Biociência, Campo Grande, MS, Brasil.
}

\begin{abstract}
It is possible to cultivate common beans for a third harvest in one agricultural year due to varietal characteristics. For calendar adequacy, performing desiccation and planting often occur almost simultaneously. Germination performance of many plant species can improve with biostimulant use on seeds, however the interaction with herbicide residual molecules is unknown. The hypothesis is that seeds treated with a biostimulant in soil with glyphosate residues can eliminate the advantage of the biostimulant or increase the damage caused by the herbicide. The aim of this study was to evaluate the effect of different glyphosate reduce doses and the interaction with biostimulant on bean seed germination and vigor. The experiment was conducted using a completely randomized $2 \times 5$ factorial block designing factorial $2 \times 5$, corresponding to the presence and absence of biostimulant and five different doses of glyphosate reduce rates, with four repetitions. The conducted evaluations were first count germination, germination test, accelerated aging, cold test, root and shoot length, root and shoot dry matter and electrical conductivity. It can be concluded that the biostimulant treatment on bean seeds increased germination, seed vigor and early seedling growth, but glyphosate presence reduced those advantages, increasing electrical conductivity. However, the herbicide presence provided higher germination on the accelerated aging test.
\end{abstract}

KEYWORDS: Herbicide. Phaseolus vulgaris. Stimulate. Hormesis.

\section{INTRODUCTION}

The common bean is the most cultivated species among the Phaseolus genus, with Brazil being among the world's largest producers. Cultivation in the country occurs throughout the year, in the "water season" corresponding to the first harvest, "the dry season" corresponding to the second harvest, and in the "winter season" corresponding to the third harvest (ABRANTES et al., 2011).

The use of biostimulants in bean crops has increased over recent years, with a focus on increasing grain yield, thus increasing the number of studies related to this crop (LANA et al., 2009). Similarly, the use of agrochemicals enables more dynamic management with faster responses to pests, disease and weed control, therefore being used more intensely. Among these, herbicides have been receiving greater prominence, representing a tool of great importance for the agricultural production system (FIGUEREDO et al., 2007).

Biostimulants correspond to several substances and microorganisms which are capable of promoting plant growth (CALVO et al. 2014).
For He et al. (2009), the use of these combined regulators in different ways is indispensable for the occurrence of physiological processes such as growth and organ development.

Biostimulants can be used for seed treatment in the sowing row groove, as well as in foliar sprays (ABRANTES et al., 2011). They can promote root growth when applied to the seeds or in early development, thus allowing greater resistance to biotic, abiotic and nutritional stresses, and consequently increase productivity (DOURADO NETO et al., 2014). They can also provide greater vigor in seed treatment, as seen for some soybean varieties (MOTERLE et al., 2011).

Glyphosate is the most widely used herbicide in the world (BASTOS; SIMONI, 2010). It is absorbed by the plant walls and by the roots, and it can remain in the soil binded to colloids, increasing its half-life in the presence of dead vegetation cover (CASSIGNEUL et al., 2016). Herbicidal action in the plants occurs at the metabolic level interrupting aromatic amino acid production, and at a molecular level with damage to tissues and membranes due to reactive oxidative radicals (KIELAK et al., 2011). 
In evaluating the initial development of bean seedlings, Oliveira et al. (2013) found that low doses of glyphosate inhibited radicle and hypocotyl formation. In a study on the hormesis effect in the common bean, Silva et al. (2012) found a reduction in the mass of 100 grains under higher doses of the herbicide. However, little is known about the interaction between glyphosate doses and the use of biostimulants in seeds of cultivated plants.

The hypothesis for this study is that the use of biostimulated seeds in soils with glyphosate residues can eliminate the advantages of the biostimulant or increase the damage caused by the herbicide. Thus, this study aimed to evaluate the effect of glyphosate reduce doses and biostimulant on common bean seeds.

\section{MATERIAL AND METHODS}

Precocious carioca variety Phaseolus vulgaris L. seeds without previous treatment were used from the production fields of the Federal University of Mato Grosso do Sul, Chapadão do Sul Campus (UFMS - CPCS). The experimental design was completely randomized according to a $2 \times 5$ factorial scheme, corresponding to the treatment of seeds with biostimulant $\left(7.5 \mathrm{~mL} \mathrm{~L}^{-1}\right.$ of water) or absence of biostimulant, and different glyphosate doses (zero; $2.2 ; 4.4 ; 6.6$ and $8.8 \mathrm{~mL} \mathrm{~L}^{-1}$ of water).

The products used were the Stimulate commercial biostimulant and Glyphosate Zapp 620. For exposure to the herbicide, the seeds were directly emerged into the solution corresponding to the treatment for 40 minutes. The evaluations performed were: the germination test, first germination count, accelerated aging, cold test, shoot and root length, shoot and root dry mass and electrical conductivity.

The germination test was performed with four replicates of 50 seeds per treatment. The seeds were arranged on germitest paper, moistened with deionized water in the proportion of 2.5 times their dry weight, rolled into rolls that were stored in plastic bags and brought to a germinator at $25^{\circ} \mathrm{C}$. The evaluations were carried out at 5 and 9 days after sowing, according to the criteria established in the Rules for Seed Analysis (BRASIL 2009). The results were expressed as percentage of germinated seedlings.

The first germination count was performed along with the germination test, and the percentage of normal seedlings at 5 days after starting the test was recorded according to the criteria established by Brasil (2009).
The Accelerated Aging test was conducted using the plastic box method (gerbox with screen) according to the recommendations by Marcos Filho (1994), using the conditions of $41^{\circ} \mathrm{C}$ for 72 hours (HAMPTON; TEKRONY, 1995). After aging the seeds were submitted to the standard germination test and evaluated at 5 days. The results were expressed as percentage of germinated seedlings.

The same methodology described in the germination test was used for the cold test; however, after the paper rolls were made they were placed inside plastic bags and taken to a BOD incubator at a temperature of $10^{\circ} \mathrm{C}$ for 3 days. After this initial period, the rolls were taken to a germinator at $25^{\circ} \mathrm{C}$ for another 5 days to evaluate the efficiency of seed germination according to the same standard germination test procedure established by Brasil (2009). The results were expressed as percentage of germinated seedlings.

Next, 80 seeds per treatment were used for evaluating shoot and root length, 20 per replicate. A longitudinal line was drawn in the upper third of the pre-moistened germination paper, over which 20 seeds were evenly spaced. The paper was rolled over, stored into plastic bags, and conditioned in a germinator at a constant controlled temperature of $25^{\circ} \mathrm{C}$ (BRASIL, 2009).

The evaluation was performed on the $5^{\text {th }}$ day, when only normal seedlings were measured. Measurements were made using a graduated ruler measuring the shoot (hypocotyl) and the primary root of the seedling. The result was expressed as the mean values in $\mathrm{cm}$. In addition to the length test, the root and shoot dry mass of the seedlings were also evaluated. For drying, the material was placed into a forced air-circulation oven at $65^{\circ} \mathrm{C}$ for 48 hours.

The electrical conductivity test was performed with four replicates of 25 seeds, which were weighed to the nearest four decimal places. They were subsequently placed in a plastic cup containing $75 \mathrm{~mL}$ of deionized water and taken to a BOD incubator at $25^{\circ} \mathrm{C}$ for 24 hours. After this period, readings of the soaking solution were performed using a conductivity meter. The results were expressed as $\mu \mathrm{S} \mathrm{cm}^{-1} \mathrm{~g}^{-1}$ (MARCOS FILHO et al., 1987).

The data were submitted to the F-test at $5 \%$ probability, followed by a comparison of means by the Tukey test and regression for the implemented doses.

\section{RESULTS}

A significant interaction was observed between the stimulant and glyphosate treatments for 
the variables first germination count $(\mathrm{FC})$, cold test (CT), shoot and root dry mass of the seedlings
(SDM and RDM), and electrical conductivity (EC) (Table 1).

Table 1. Summary of analysis of variance and mean values for the first germination count (FC), germination test (GT), accelerated aging (AA), cold test (CT), shoot growth of the seedlings (SG), root growth of the seedlings (RG), shoot dry mass (SDM), root dry mass (RDM) and electrical conductivity (EC) of bean seeds submitted to biostimulant application under glyphosate doses.

\begin{tabular}{|c|c|c|c|c|c|c|c|c|c|}
\hline & $\mathrm{FC}$ & GT & AA & $\mathrm{CT}$ & SG & $\mathrm{RG}$ & SDM & $\mathrm{RDM}$ & $\mathrm{EC}$ \\
\hline \multicolumn{10}{|l|}{ Stimulate } \\
\hline Ausence & 33.55 & $57.55 \mathrm{~b}$ & 26.90 & 13.15 & 2.47 & $3.26 \mathrm{~b}$ & 0.13 & 0.04 & 81.68 \\
\hline Presence & 41.60 & $65.15 \mathrm{a}$ & 25.25 & 14.30 & 2.60 & $3.49 \mathrm{a}$ & 0.14 & 0.04 & 95.05 \\
\hline \multicolumn{10}{|l|}{ Glyphosate } \\
\hline 0.0 & 59.87 & 86.50 & 22.37 & 30.62 & 3.64 & 6.99 & 0.25 & 0.08 & 71.50 \\
\hline 2.2 & 49.50 & 64,00 & 24.12 & 15.75 & 2.42 & 3.09 & 0.17 & 0.04 & 80.38 \\
\hline 4.4 & 36.12 & 59.37 & 26.62 & 8.87 & 2.33 & 2.56 & 0.11 & 0.03 & 88.37 \\
\hline 6.6 & 25.87 & 53.62 & 27.62 & 7.25 & 2.20 & 2.27 & 0.09 & 0.02 & 96.35 \\
\hline 8.8 & 16.50 & 43.25 & 29.62 & 6.12 & 2.08 & 1.98 & 0.07 & 0.02 & 104.33 \\
\hline \multicolumn{10}{|l|}{ F test } \\
\hline Stimulate & $76.15^{*}$ & $25.42 *$ & $3.41^{\mathrm{ns}}$ & $3.80^{\mathrm{ns}}$ & $3.25^{\mathrm{ns}}$ & $35.60^{*}$ & $3.56^{\mathrm{ns}}$ & $2.88^{\mathrm{ns}}$ & 134.02* \\
\hline Glyphosate & $287.34 *$ & $90.72 *$ & $8.21^{*}$ & $237.27^{*}$ & $60.69^{*}$ & $2384.30 *$ & $124.80^{*}$ & $175.79 *$ & $96.98^{*}$ \\
\hline Stim*Glyph & $33.06^{*}$ & $1.69^{\mathrm{ns}}$ & $0.11^{\mathrm{ns}}$ & $31.90 *$ & $2.30^{\mathrm{ns}}$ & $0.91^{\mathrm{ns}}$ & $9.84 *$ & $6.53^{*}$ & $5.58 *$ \\
\hline CV (\%) & 7.76 & 7.77 & 10.84 & 13.59 & 9.03 & 3.53 & 13.80 & 12.95 & 4.13 \\
\hline
\end{tabular}

$* \mathrm{e}^{\mathrm{ns}}$ - significant at $5 \%$ probability and not significant by the F-test; Means followed by different letters in the column differ by the Tukey test at $5 \%$ probability; $\mathrm{CV}$ - coefficient of variation.

The presence of the stimulant provided greater germination (GT) of bean seeds (Table 1), which was reduced in the presence of glyphosate, in which the higher the dose of the herbicide, the greater the reduction (Figure 1).

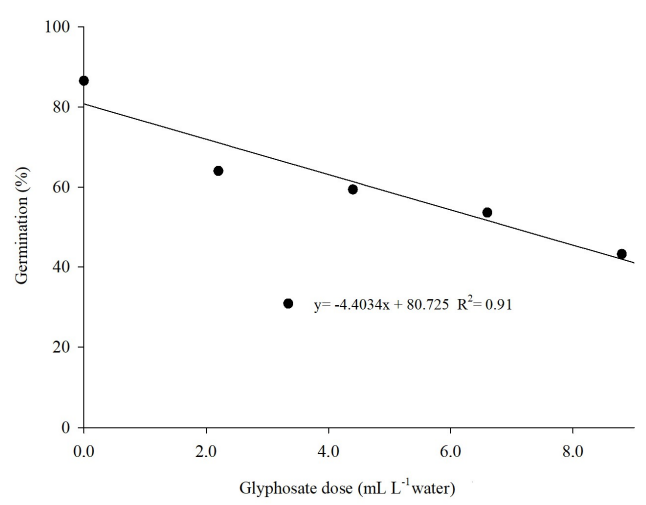

Figure 1. Germination of common bean seedlings under glyphosate doses.

The results of the interactions are shown in Table 2. The presence of stimulant provided greater seed vigor, confirmed by the higher percentage of normal seedlings in the FC and the CT, as well as higher values for SDM and RDM in the absence of glyphosate. However, the vigor of the seeds treated with biostimulant was reduced when in the presence of the herbicide after $4.4 \mathrm{~mL} \mathrm{~L}^{-1}$ for the $\mathrm{FC}$ and 2.2 $\mathrm{mL} \mathrm{L}^{-1}$ in the CT. The presence of the biostimulant halved the number of normal seedlings for the highest dose of glyphosate in the CT.

The biostimulant favored dry mass accumulation in bean seedlings in the absence and at the lowest dose $\left(2.2 \mathrm{~mL} \mathrm{~L}^{-1}\right)$ of the herbicide, however eliminating this advantage at higher doses of the glyphosate. The electrical conductivity of the seeds was higher whenever the stimulant was applied. 
Table 2. Result of the interactions for first germination count (FC), cold test (CT), shoot dry mass (SDM), root dry mass (RDM) and electrical conductivity (EC) of bean seeds submitted to an application of biostimulant under glyphosate doses.

\begin{tabular}{|c|c|c|c|c|c|}
\hline \multirow[t]{2}{*}{ Evaluated parameter } & \multicolumn{5}{|c|}{ Glyphosate dose $\left(\mathrm{mL} \mathrm{L}^{-1}\right)$} \\
\hline & 0.0 & 2.2 & 4.4 & 6.6 & 8.8 \\
\hline \multicolumn{6}{|l|}{$\mathrm{FC}$} \\
\hline Absence & $47.25 b$ & $43.00 \mathrm{~b}$ & $32.50 \mathrm{~b}$ & $28.50 \mathrm{a}$ & $16.50 \mathrm{a}$ \\
\hline Presence & $72.50 \mathrm{a}$ & $56.00 \mathrm{a}$ & $39.75 \mathrm{a}$ & $23.25 b$ & $16.50 \mathrm{a}$ \\
\hline \multicolumn{6}{|l|}{ CT } \\
\hline Absence & $24.00 \mathrm{~b}$ & $14.00 \mathrm{~b}$ & $10.50 \mathrm{a}$ & $9.00 \mathrm{a}$ & $8.25 \mathrm{a}$ \\
\hline Presence & $37.25 \mathrm{a}$ & $17.50 \mathrm{a}$ & $7.25 b$ & $5.50 \mathrm{~b}$ & $4.00 \mathrm{~b}$ \\
\hline \multicolumn{6}{|l|}{ SDM } \\
\hline Absence & $0.22 \mathrm{~b}$ & $0.14 b$ & $0.12 \mathrm{a}$ & $0.09 \mathrm{a}$ & $0.06 \mathrm{a}$ \\
\hline Presence & $0.28 \mathrm{a}$ & $0.20 \mathrm{a}$ & $0.09 \mathrm{a}$ & $0.08 \mathrm{a}$ & $0.08 \mathrm{a}$ \\
\hline \multicolumn{6}{|l|}{$\mathrm{RDM}$} \\
\hline Absence & $0.07 \mathrm{~b}$ & $0.03 b$ & $0.03 \mathrm{a}$ & $0.02 \mathrm{a}$ & $0.02 \mathrm{a}$ \\
\hline Presence & $0.08 \mathrm{a}$ & $0.05 \mathrm{a}$ & $0.03 \mathrm{a}$ & $0.02 \mathrm{a}$ & $0.01 \mathrm{~b}$ \\
\hline \multicolumn{6}{|l|}{$\mathrm{EC}$} \\
\hline Absence & $67.58 b$ & $76.39 \mathrm{~b}$ & $81.30 \mathrm{~b}$ & $86.82 b$ & $96.32 \mathrm{~b}$ \\
\hline Presence & $75.42 \mathrm{a}$ & $83.23 \mathrm{a}$ & $100.30 \mathrm{a}$ & $106.81 \mathrm{a}$ & $109.48 \mathrm{a}$ \\
\hline
\end{tabular}

Means followed by different letters in the column differ by the Tukey test at $5 \%$ probability.

The FC reduced with the increase in the Glyphosate doses for both with and without stimulant treatment. However, the reduction was greater for the treatment that received the biostimulant, with a decrease of approximately $77 \%$ for the FC for the highest dose of the herbicide compared to its absence. The reduction was $65 \%$ in the absence of stimulant (Figure 2).

The AA test showed that the increase in herbicide doses also increased germination accordingly (Figure 3).

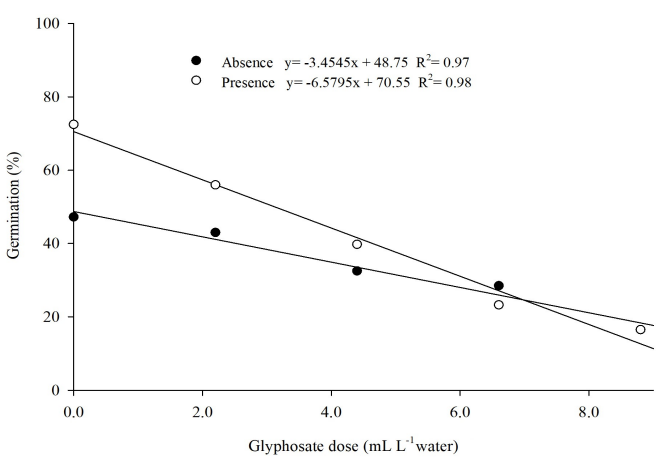

Figure 2. First germination count of bean seedlings submitted to biostimulant application under glyphosate doses.

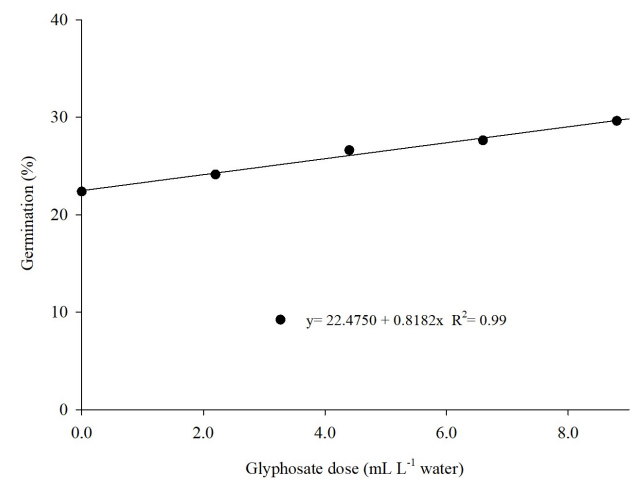

Figure 3. Accelerated Aging test for bean seedlings submitted to biostimulant application under glyphosate doses. 
CT showed a reduction in the number of normal seedlings in the presence of glyphosate for treatments with the absence and presence of biostimulant (Figure 4). The glyphosate dose of 7 $\mathrm{mL} \mathrm{L}^{-1}$ presented the lowest germination value in the presence and absence of the biostimulant.

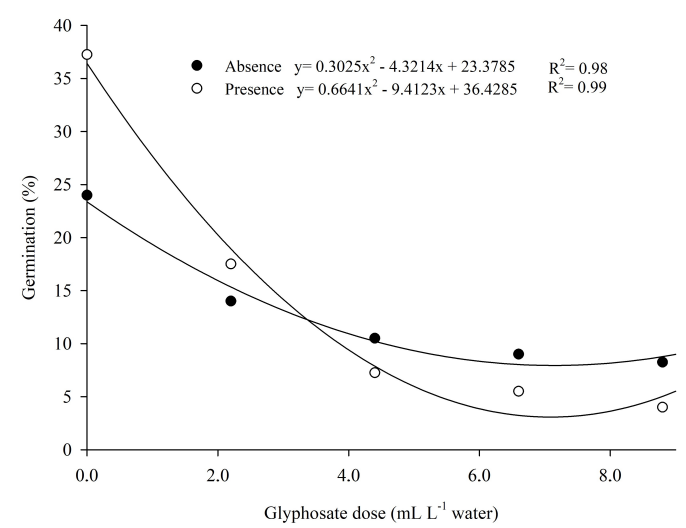

Figure 4. Cold test in bean seedlings submitted to biostimulant application under glyphosate doses.

Figures 5 and 6 show that there was a reduction in bean seedlings shoot and root growth in the presence of glyphosate. The herbicide dose that provided the lowest SG was approximately $6.8 \mathrm{~mL}$ $\mathrm{L}^{-1}$, and $6.64 \mathrm{~mL} \mathrm{~L}^{-1}$ for $\mathrm{RG}$.

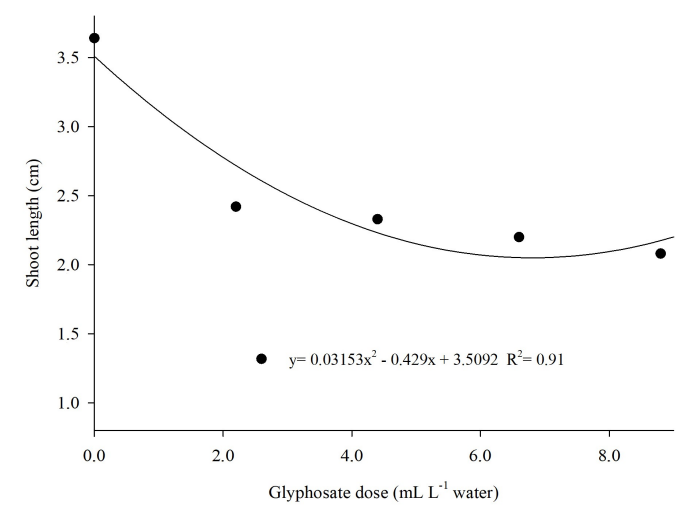

Figure 5. Shoot growth test of bean seedlings under glyphosate doses.

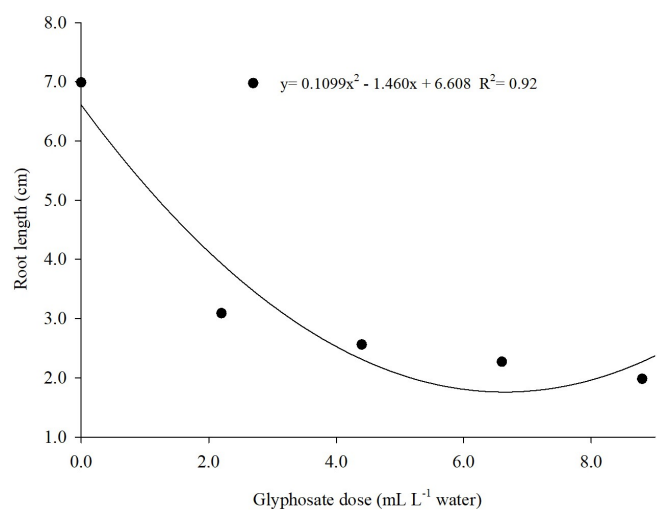

Figure 6. Root growth test of bean seedlings under glyphosate doses.

Shoot (Figure 7) and root (Figure 8) dry mass accumulation followed the same trend of SG and $R G$ reduction when the herbicide is used. It is worth noting that the presence of the biostimulant is capable of providing higher SDM and RDM values up to the dose of $2.2 \mathrm{ml} \mathrm{L}^{-1}$ (Table 2). 


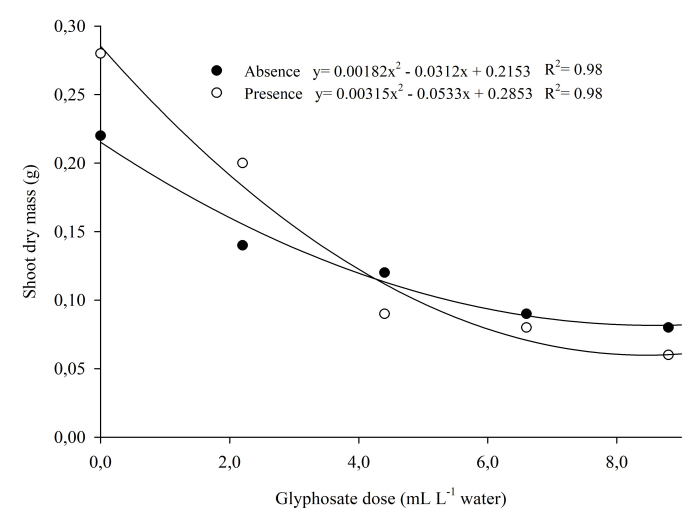

Figure 7. Shoot dry mass of bean seedlings in the absence and presence of stimulant treatment under glyphosate doses.

Lower SDM values were found for the doses of $8.57 \mathrm{~mL} \mathrm{~L}^{-1}$ in the absence and of $8.46 \mathrm{~mL}$ $\mathrm{L}^{-1}$ in the presence of the biostimulant. For the RDM values, the lowest values were observed for the doses of $6.89 \mathrm{~mL} \mathrm{~L}^{-1}$ of glyphosate in the absence of biostimulant, and of $8.56 \mathrm{~mL} \mathrm{~L}^{-1}$ in its presence.
Figure 9 shows higher electrical conductivity as the glyphosate dose increased for treatments in the absence and presence of stimulant.

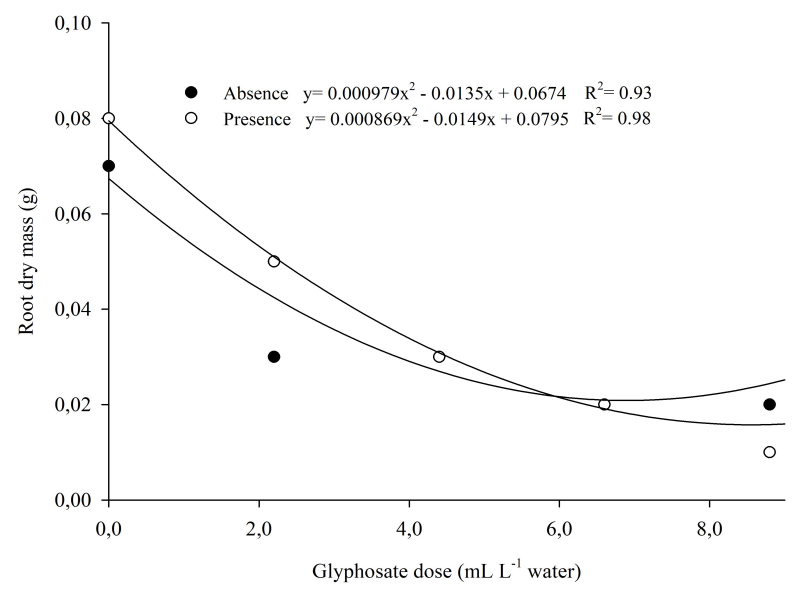

Figure 8. Root dry mass of bean seedlings in the absence and presence of stimulant treatment under glyphosate doses.

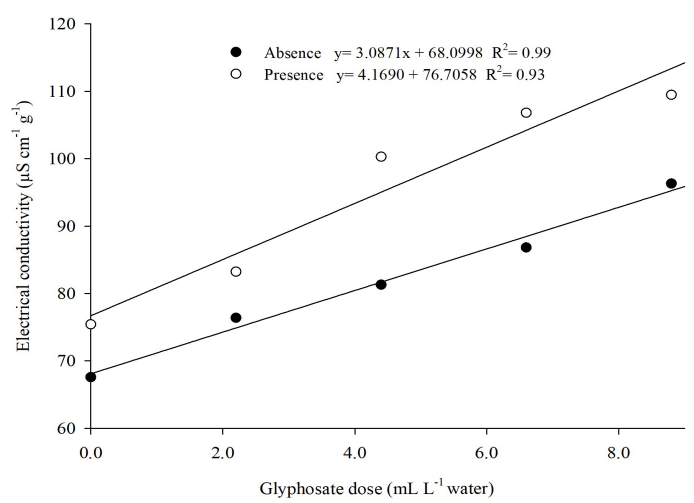

Figure 9. Electrical conductivity of bean seedlings submitted to biostimulant application under glyphosate doses. 


\section{DISCUSSION}

The use of the biostimulant products which contain substances with hormonal action for vegetables in its formula such as auxin, gibberellin and cytokinin, provided a higher germination rate for common bean seeds (Table 1). Among these substances, the most studied for their germinative process is gibberellin, which was probably responsible for the obtained result. The review by Obroucheva (2012) indicates the performance of this hormone in promoting germination through the induction of hydrolytic enzymes such as cysteine proteinase and others that convert triglycerides into sugar, releasing energy for embryonic development.

This effect has been verified in several plant species. Zanotti et al. (2014) observed that gibberellin was responsible for promoting greater mobilization of lipids in papaya seeds, and it can also be the substrate for producing energy for the germination process in the gluconeogenesis process, according to Heldt and Piechulla (2011). In their evaluations, the use of gibberellin in seed treatment was effective in promoting almost double the germination in relation to the control treatment.

The presence of glyphosate in the seeds resulted in an opposite effect to the biostimulant, and the higher the dose used, the more damage caused to the germination (Figure 1). This is a broad-spectrum systemic herbicide that deregulates the shikimate acid pathway by inhibiting the 5enolpyruvyl-chiquimate-3-phosphate synthase (EPSPS), preventing the formation of phenylalanine, tyrosine and tryptophan aromatic amino acids and other metabolic products that depend on them (MOLDES et al., 2008). Thus, the deficiency of these amino acids compromises the protein synthesis necessary for plant development, and reduced the bean germination. Melhorança Filho et al. (2011) also verified that small doses of glyphosate were harmful to soybean germination, even in transgenic cultivars.

The result of the first germination count reveals that the use of the biostimulant favors greater vigor in bean seedlings (Table 2). This was caused by the product constituent hormones, which according to Moterle et al. (2011), are capable of stimulating cell division and cell elongation, ensuring a higher percentage of germinated seedlings in the first germination count. Another action mentioned is the stimulus to the degradation and mobilization of reserves, which guarantees better initial development in the seedlings.

Surprisingly the seeds treated with glyphosate doses obtained better performance in the accelerated aging test, although the germination values decreased considerably in relation to the total germination (Figure 3). Some studies are based on the hormonal effect of glyphosate at low doses (SILVA et al., 2012), however its effect on seed vigor, especially in the proposed test, is still unknown. Binotti et al. (2008) found that the accelerated aging test in beans results in seed loss of cellular constituents, reserves such as amino acids and sugars, and important molecules like potassium and phosphorus, as observed in the leachate by the electrical conductivity test. This is due to damage and disruption of membranes which affects the germination potential of the seeds.

One of the main causes of membrane deterioration is the excessive production of reactive oxygen species (ROS) caused by the increased rate of cellular respiration due to the conditions to which the seeds are subjected in the accelerated aging test (TIAN et al., 2008). Nevertheless, ROS can also play a key role in seed germination after soaking when they are produced by the embryonic axis. In this case, they are responsible for expressing genes related to key enzymes of the germinative process; in addition, they interact with several classes of hormones that regulate dormancy and seed germination processes. This relationship was verified by Ishibashi et al. (2013), in which the production of ROS after soaking soybean seeds stimulated ethylene production, which was essential for embryonic development.

Several studies have shown that ethylene can stimulate the germination process in different plant species, acting (for example) in mobilizing protein and carbohydrate reserves in the Sesbania virgata tree legume (TONINI et al., 2010), breaking dormancy in carrots by thermoinhibition (NASCIMENTO et al., 2013), and promoting the germination of Stylosanthes guianensis under saline stress (SILVA et al., 2014). The review carried out by Corbineau et al. (2014) shows that this hormone plays a fundamental role in regulating germination, along with the most studied hormones in the process, abscisic acid and gibberellic acid. What we propose in this study is that the presence of glyphosate in small doses provided an increase in the ethylene content in the seeds, and ended up favoring the germination after accelerated aging.

No effects of glyphosate doses interacting in the production of hormones in plant seeds is found in the literature; however, some studies mention the increase of the ethylene content in plant tissues in contact with the herbicide (ABU-IRMAILEH et al., 1979; GALLI; MONTEZUMA, 2005; YAMADA; CASTRO, 2007). Another indication that this may 
occur is found in the study by Miteva et al. (2010) and Kielak et al. (2011), in which the herbicide leads to cellular oxidative stress. As previously mentioned, ROS production in the seeds can stimulate ethylene synthesis, in this case being fundamental for better germinative development (ISHIBASHI et al., 2013).

In the cold test, the use of the biostimulant increased the number of germinated plants, although in the glyphosate presence this effect has been reversed (Table 2). The biostimulant action reflected in the higher resistance of the plants to low temperatures. As in the first count, the greater seed activity attributed to consuming reserves makes the seedling healthier. The seeds with biostimulant obtained inferior germination results at doses above $3.5 \mathrm{~mL} \mathrm{~L}^{-1}$ of glyphosate.

As the perfect functioning of protein synthesis is essential for developing healthy seedlings, higher germination and growth performance with the use of stimulant may have caused a higher number of abnormal seedlings in the presence of the herbicide. Moterle et al. (2011) found that the use of glyphosate doses led to a higher number of defective seedlings due to the deficiency in aromatic amino acids.

The growth and accumulation of dry mass in bean seedlings presented corresponding results. Auxin, gibberellin and cytokinin are hormones that effectively participate in plant development. While the first two are involved in growth, cytokinin is essential for forming new tissues through promoting cell division. Santos et al. (2013) found higher total length of sunflower seedlings with the use of stimulant, relating this result to the ability of auxin and cytokinin to stimulate root development. In beans, Custódio et al. (2013) found that the application of auxins led to greater stem or root development, depending on the implemented dose. Higher doses led to greater stem development, while lower doses favored the accumulation of matter in the root system.

Contact of the seeds with glyphosate reduced the growth (Figure 5 and 6) and the accumulation of dry mass of the seedlings (Figure 7 and 8 ), and the advantage of using the biostimulant was suppressed at doses higher than $2.2 \mathrm{~mL} \mathrm{~L}^{-1}$ of the herbicide (Table 2). The harm caused by interrupting the aromatic amino acids formation results in halting processes such as mitosis, causing direct damage to root development and dry mass accumulation. Thus, it becomes impossible to sustain greater growth due to hormonal stimulation. The same effect was verified in soybean seedlings in the study by Melhorança Filho et al. (2011).

The increase in electrical conductivity caused by glyphosate, evidences damage to membrane integrity, and explains the adverse effects of herbicide contact with seeds (Table 2) This was also verified in soybean seeds (BERVALD et al., 2010) and in wheat (BELLÉ et al., 2014). The herbicide was used as desiccant for subsequent seeding in both cases. Already Bervald et al. (2010), soaked soybean seeds in glyphosate solution and, similar to this study, verified higher electrolytes extravasation and reduced germination.

Miteva et al. (2010) studied the response in production of antioxidant enzymes by peas in contact with glyphosate. The results showed that the oxidative stress caused by the herbicide promoted an increase of the enzyme responsible for the reaction against oxidative radicals and hydrogen peroxide. In a similar way, Kielak et al. (2011) found higher catalase, ascorbate peroxidase and polyamine activity in response to the higher putrescine content. Thus, there are strong indications of the oxidant activity of glyphosate, with membrane damages, besides a side effect on the shikimate pathway, leading to amino acid deficiency.

Although the electrical conductivity of the treatments that received stimulant were higher (Table 2), we can verify that this effect was not detrimental to the development of the plants in the absence of the herbicide, as the best germination results, first germination count, root length and shoot and root dry mass were found precisely with the aid of the biostimulant.

\section{CONCLUSIONS}

The treatment of bean seeds with stimulant increases seedling germination. Seeds treated with stimulant showed higher vigor, growth rate and dry matter accumulation; however, the presence of glyphosate eliminates the advantages of the biostimulant, reducing the vigor due to the greater electrical conductivity.

The presence of glyphosate doses reduces common bean seed germination and vigor, but it increases germination when they are submitted to accelerated aging.

RESUMO: Devido às características de variedades de feijoeiro comum, é possível seu cultivo como terceira safra em um ano agrícola. Para adequação ao calendário, a prática de dessecação e plantio muitas vezes 
ocorrem quase simultaneamente. A utilização de bioestimulantes em sementes pode aumentar o desempenho germinativo de diversas espécies de plantas, no entanto a sua interação com moléculas residuais de herbicidas é desconhecido. A hipótese é que o uso de sementes tratadas com bioestimulante em solos com resíduos de glifosato pode eliminar as vantagens do primeiro ou amentar os danos causados pelo herbicida. $\mathrm{O}$ objetivo do trabalho foi avaliar o efeito de subdoses de glifosato e bioestimulante em sementes de feijoeiro. $\mathrm{O}$ experimento foi realizado em blocos inteiramente casualizados em fatorial $2 \times 5$, correspondendo a ausência e presença de bioestimulante e cinco subdoses de glifosato, com quatro repetições. As avaliações foram primeira contagem de germinação, teste de germinação, envelhecimento acelerado, teste de frio, comprimento de parte aérea e de raiz, massa seca de parte aérea e de raiz e condutividade elétrica. Conclui-se que o tratamento de sementes de feijoeiro com bioestimulante eleva a germinação, o vigor de sementes e o crescimento inicial de plântulas, porém a presença de glifosato elimina essas vantagens, revelando maior condutividade elétrica. No entanto, a presença do herbicida proporciona maior germinação no teste de envelhecimento acelerado.

PALAVRAS-CHAVE: Herbicida. Phaseolus vulgaris. Stimulate. Hormese.

\section{REFERENCES}

ABRANTES, F. L., SÁ, M. E., SOUZA, L. C. D., SILVA, M. P., SIMIDU, H. M., ANDREOTTI, H., BUZETTI, S., VALÉRIO FILHO, W. V., ARRUDA, N. Uso de regulador de crescimento em cultivares de feijão de inverno. Pesquisa Agropecuária Tropical, v. 41, n. 2, p. 148-154, 2011. http://dx.doi.org/ 10.5216/pat.v41i2.8287

ABU-IRMAILEH, B. E., JORDAN, L. S., KUMAMOTO, J. Enhancement of $\mathrm{CO}_{2}$ and ethylene production and celulase activity by glyphosate in Phaseolus vulgaris. Weed Science, v. 27, n. 1, p. 103-106, 1979. https://doi.org/10.1017/S0043174500043587

BASTOS, F. A., SIMONI, J. A. Determinação da variação de entalpia da interação entre o herbicida glifosato e os íons cálcio, cobre, zinco e alumínio em solução aquosa por calorimetria por titulação isotérmica.

AugmDomus, v. 2, p. 60-71, 2010. Avalaible at: < http://hdl.handle.net/10915/15902>. Accessed may. 10 2018.

BELLÉ, C., KULCZYNSKI, S. M., BASSO, C. J., KASPARY, T. E., LAMEGO, F. P., PINTO, M. A. B. Yield and quality of wheat seeds as a function of desiccation stages and herbicides. Journal of Seed Science, v. 36, n. 1, p. 63-70, 2014. http://dx.doi.org/10.1590/S2317-15372014000100008

BERVALD, C.M.P., MENDES, C.R., TIMM, F.C., MORAES, D.M., BARROS, A.C.S.A., PESKE, S.T. Desempenho fisiológico de sementes de soja de cultivares convencional e transgênica submetidas ao glifosato. Revista Brasileira de Sementes, v. 32, n. 2, p. 09-18, 2010. http://dx.doi.org/10.1590/S010131222010000200001

BINOTTI, F. F. S., HAGA, K. I., CARDOSO, E. D., ALVES, C. Z., SÁ, M. E., ARF, O. Efeito do período de envelhecimento acelerado no teste de condutividade elétrica e na qualidade fisiológica de sementes de feijão. Acta Scientiarum Agronomy, Maringá, v. 30, n. 2, p. 247-254, jun. 2008. http://dx.doi.org/10.1590/S180786212008000200014

BRASIL. Ministério da Agricultura, Pecuária e Abastecimento. Regras para análise de sementes. Secretaria de Defesa Agropecuária. Mapa/ACS: Brasília. 2009. 399 p.

CALVO, P., NELSON, L., KLOEPPER, J. W. Agricultural uses of plants biostimulants. Plant and Soil, Crawley. v. 383, n. 1/2, p. 3-41, 2014. https://doi.org/10.1007/s11104-014-2131-8

CASSIGNEUL, A., BENOIT, P., BERGHEAUD, V., DUMENY, V., ETIÉVANT, V., GOUBARD, Y., MAYLIN, A., JUSTES, E., ALLETTO, L. 2016. Fate of glyphosate and degradates in cover crop residues and 
underlying soil: a laboratory study. Science of the Total Environment, v. 545-546, p. 582 - 590, 2016. https://doi.org/10.1016/j.scitotenv.2015.12.052

CORBINEAU, F., XIA, Q, BAILLY, C., EL-MAAROUF-BOUTEAU, H. Ethylene, a key fator in the regulation of seed dormancy. Frontiers in Plant Science, v. 5, p. 1-13, 2014.

https://doi.org/10.3389/fpls.2014.00539

DOURADO NETO, D.; DARIO, G. J. A., BARBIERI, A. P. P., MARTIN, T. N. Ação de bioestimulante no desempenho agronômico de milho e feijão. Bioscience Journal, v. 30, n. 3, p. 371-379, 2014. Avalaible at: < //www.seer.ufu.br/index.php/biosciencejournal/article/view/18110>. Accessed oct. 172019.

FIGUEREDO, S. S.; LOECK, A. E.; ROSENTHAL, M. D., AGOSTINETTO, D., FONTANA, L. C., RIGOLI, R. P. Influência de doses reduzidas do glyphosate no tomateiro (Lycopersicon esculentum). Planta Daninha, v. 25, n. 4, p. 849-857, 2007. http://dx.doi.org/10.1590/S0100-83582007000400022.

GALLI, A. J. B.; MONTEZUMA, M. C. Alguns aspectos da utilização do herbicida glifosato na agricultura. Santo André: Acadcom Editora, 2005. 66 p.

HAMPTON, J. G., TEKRONY, D. M. Handbook of vigor test methods. ed. 3. Zürich: International Seed Testing Association, 1995. 117 p.

HE, J., YU, S., MA, C. Effects of plant growth regulator on endogenous hormone levels during the of the red globe growth. Journal of Agricultural Science, v. 1, n. 1, p. 92-100, 2009.

http://dx.doi.org/10.5539/jas.v1n1p92.

HELDT, H. W., PIECHULLA, B. 4 ed. Plant biochemistry. Burlington Academic Press: Elsevier, 2011. 656 p.

ISHIBASHI, Y., KODA, Y., ZHENG, S. H., YUASA, T., IWAYA-INOUE, M. Regulation of soybean seed germination through ethylene production in response to reactive oxygen species. Annals of Botany, v. 111, n. 1, p. 95-102, 2013. https://doi.org/10.1093/aob/mcs240.

KIELAK, E., SEMPRUCH, C., MIODUSZEWSKA, H., KLOCEK, J., LESZCZY'NSKI, B. Phytotoxicity of Roundup Ultra 360 SL in aquatic ecosystems: Biochemical evaluation with duckweed (Lemna minor L.) as a model plant. Pesticide Biochemistry and Physiology, v. 99, n. 3, p. 237-243, 2011.

https://doi.org/10.1016/j.pestbp.2011.01.002.

LANA, R. M. Q., LANA, A. M. Q., GOZUEN, C. F., BONOTO, I., TREVISAN, L. R. Aplicação de reguladores de crescimento na cultura do feijoeiro. Bioscience Journal, v. 25, n. 1, p. 13-20, 2009. Avalaible at: < http://www.seer.ufu.br/index.php/biosciencejournal/article/view/6699>. Accessed oct. 172019.

NASCIMENTO, W. M., HUBER, D. J., CANTLIFFE, D. J. Carrot seed germination and ethylene production at high temperature in response to seed osmopriming. Horticultura Brasileira, v. 31, n. 4, p. 554-558, 2013. http://dx.doi.org/10.1590/S0102-05362013000400008

MARCOS FILHO, J., CÍCERO, S. M., SILVA, W. R. Avaliação da qualidade das sementes. Piracicaba: FEALQ/ESALQ, 1987.230 p.

MARCOS FILHO, J. Teste de envelhecimento acelerado. In: VIEIRA, R. D., CARVALHO, N. M. (ed.). Testes de vigor em sementes. Jaboticabal: Funep, 1994. 164 p.

MELHORANÇA FILHO, A. L., PEREIRA, M. R. R., MARTINS, D. Efeito de subdoses de glyphosate sobre a germinação de sementes das cultivares de soja rr e convecional. Bioscience Journal, v. 27, n. 5, p. 686-691, 2011. Avalaible at: $<$ http://www.seer.ufu.br/index.php/biosciencejournal/article/view/11300 $>$. Accessed oct. 172019. 
MITEVA, L. P. E., IVANOV, S. V., ALEXIEVA, V. S. Alterations in glutathione pool and some related enzymes in leaves and roots of pea plants treated with the herbicide glyphosate. Russian Journal of Plant Physiology, v. 57, n. 1, p. 131-136, 2010. https://doi.org/10.1134/S1021443710010188.

MOLDES, C. A., MEDICI, L. O., ABRAHÃO, O. S., TSAI, S. M., AZEVEDO, R. A. Biochemical responses of glyphosate resistant and susceptible soybean plants exposed to glyphosate. Acta Physiologiae Plantarum, v. 30, n. 4, p. 469-479, 2008. https://doi.org/10.1007/s11738-008-0144-8.

MOTERLE, L. M., SANTOS, R. F., SCAPIM, C. A., BRACCINI, A. L., BONATO, C. M., CONRADO, T. 2011. Efeito de biorregulador na germinação e no vigor de sementes de soja. Revista Ceres, v. 58, n. 5, p. 651660, 2011. http://dx.doi.org/10.1590/S0034-737X2011000500017

OBROUCHEVA, N. V. 2012. Transition from hormonal to nonhormonal regulation as exemplified by seed dormancy release and germination triggering. Russian Journal of Plant Physiology, v. 59, n. 4, p. 546-555, 2012. https://doi.org/10.1134/S1021443712040097.

OLIVEIRA, R. S. G. P., SILVA, J. E. N., SILVA, F. C. C., BEZERRA, J. L. S., MELHORANÇA FILHO, A. L. Efeito de subdoses de glifosato sobre germinação e desenvolvimento inicial do feijoeiro. Revista Eletrônica de Biologia, v. 6, n. 1, p. 35-47, 2013. Avalaible at: < https://revistas.pucsp.br/reb/article/view/9003>. Accessed oct. 172019.

SANTOS, C. A. C., PEIXOTO, C. P., VIEIRA, E. L., CARVALHO, E.V., PEIXOTO, V. A. B. 2013.

Stimulate ${ }^{\circledR}$ na germinação de sementes, emergência e vigor de plântulas de girassol. Bioscience Journal, v. 29, n. 2, p. 605-616, 2013. Avalaible at:

$<$ http://www.seer.ufu.br/index.php/biosciencejournal/article/view/14091>. Accessed oct. 172019.

SILVA, J. C., ARF, O., GERLACH, G. A. X., KURYIAMA, C. S., RODRIGUES, R. A. F. Efeito hormese de glyphosate em feijoeiro. Pesquisa Agropecuária Tropical, v. 42, p. 295-302, 2012.

http://dx.doi.org/10.1590/S1983-40632012000300008

SILVA, P. O., MEDINA, E. F., BARROS, R. S., RIBEIRO, D. M. Germination of salt-stressed seeds as related to the ethylene biosynthesis ability in three Stylosanthes species. Journal of Plant Physiology, v. 171, n. 1, p. 14-22, 2014. https://doi.org/10.1016/j.jplph.2013.09.004.

TIAN, X., SONG, S., LEI, Y. Cell death and reactive oxygen species metabolism during accelerated ageing of soybean axes. Russian Journal of Plant Physiology, v. 55, n. 1, p. 33-40, 2008.

https://doi.org/10.1134/S1021443708010032.

TONINI, P. P., PURGATTO, E., BUCKERIDGE, M. S. Effects of abscisic acid, ethylene and sugars on the mobilization of storage proteins and carbohydrates in seeds of the tropical tree Sesbania virgata (Leguminosae). Annals of Botany, v. 106, n. 4, p. 607-616, 2010. https://doi.org/10.1093/aob/mcq159.

YAMADA, T., CASTRO, P.R.C. Efeito do glifosato nas plantas: implicações fisiológicas e agronômicas. Georgia: International Plant Nutrition Institute, 2007. 32 p. (Informações Agronômicas, 119). Available at $<$ https://www.stopogm.net/old/sites/stopogm.net/files/webfm/plataforma/EfeitosGlifosatoPlantasImplica\%C3\% A7\%C3\%B5es.pdf>. Accessed may. 102018.

ZANOTTI, R. F., DIAS, D. C. F. S., BARROS, R. S., DAMATTA, F. M., OLIVEIRA, G. L. Germination and biochemical changes in 'Formosa' papaya seeds treated with plant hormones. Acta Scientiarum Agronomy, v. 36, n. 4, p. 435-442, 2014. http://dx.doi.org/10.4025/actasciagron.v36i4.18057. 